\title{
On the distribution of Dunhenvedia odontoplax Sars, 1901 in freshwaters of São Paulo State, Brazil
}

\author{
Santos-Wisniewski, MJ. ${ }^{\mathrm{a} *}$, Rocha, $O{ }^{\mathrm{b}}{ }^{\mathrm{b}}$ and Matsumura-Tundisi, ${ }^{\mathrm{c}}{ }^{\mathrm{c}}$

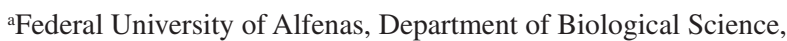 \\ Rua Gabriel Monteiro da Silva, 714, CEP 37130-000, Alfenas, MG, Brazil \\ ${ }^{\mathrm{b}}$ Federal University of São Carlos, Department of Ecology and Evolutionary Biology, \\ CP 676, CEP 13565-905, São Carlos, SP, Brazil \\ 'International Institute of Ecology - São Carlos, Rua Bento Carlos, 750, CEP 13560-000, São Carlos, SP, Brazil \\ *e-mail: mjw@unifal-mg.edu.br \\ Received July 24, 2006 - Accepted July 27, 2007 - Distributed November 30, 2007
}

(With 2 figures)

The microcrustacean Dunhenvedia odontoplax (Figure 1), which belongs to the sub-famíly Aloninae (Cladocera Chydoridae), occurs commonly in Neotropical freshwater (Smirnov, 1996). In Brazil, it was first reported in São Paulo State by Sars (1901), and later in the states of Roraima, by Smirnov and Santos-Silva (1995), Pernambuco, by Brehm $(1937,1938)$ and Rio Grande do Sul, by Montú and Gloeden (1986), indicating a wide latitudinal distribution. In the Paraná River basin, the Dunhenvedia odontoplax was observed to occur throughout the year, in both lentic and lotic habitats (Ferrato, 1967). This species was also reported in floodplain lakes, in this same basin, by Sendacz et al. (1983).

In the present study, the geographical distribution of this species in São Paulo State is analyzed, from a large number of samples. This paper is a result of the Subproject "Zooplankton diversity and the state of degradation of São Paulo State freshwaters", part of the Biota/ FAPESP Program - The Institute of Virtual Biodiversity (www.biotasp.org.br).

Zooplankton communities of 22 water-resource management units (Figure 2), referred to henceforth as UGRHi (Unidades de Gerenciamento dos Recursos Hídricos) were sampled between 9/9/1999 and 28/8/2002,
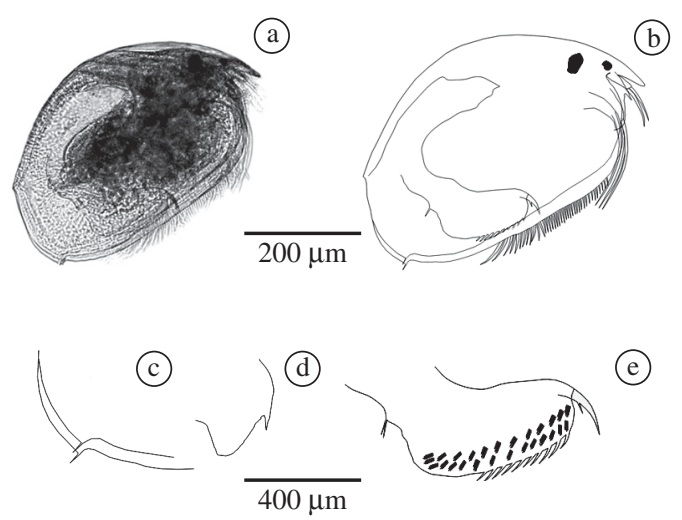

Figure 1. a and b) General view of Dunhenvedia odontoplax c) carapace posterior part d) labrum; and e) Post abdomen. giving a total of 373 samples from 223 water-bodies, which ranged from small streams, through rivers, ponds and lakes up to large reservoirs. In the very small waterbodies, only the littoral zone was sampled, while in bigger ones, both littoral and limnetic zones were sampled.

This species was found inside a restricted geographic area, occurring in only seven water bodies located in five UGRHi and was therefore considered a rare species. It occurred in the following UGRHI: Sapucaí/ Grande, Tietê/Batalha, Baixo Tietê, Aguapeí and Peixe. In the Sapucaí/Grande unit D. odontoplax was collected from the littoral region of the Volta Grande Reservoir, associated with macrophytes, whereas in the Tietê/Batalha UGRHi it was found in the Pongaí arm of Promissão Reservoir, also in the littoral region. In the Baixo Tietê UGRHi, on the other hand, D. odontoplax occurred in the large reservoirs Três Irmãos (Água Fria Stream) (and Jupiá (near dam). It also occurred in the unit Peixe near the mouth of the river Peixe and in two water bodies in the unit Aguapeí (Marreco pond and Tupã reservoir). Marreco Pond is highly eutrophic and densely covered by macrophytes, mainly Nymphaea sp. It has the highest species richness and abundance of Chydoridae recorded in the water bodies in the Biota Project sampling program. Physical and chemical variables measured in these water bodies are summarized in Table 1 . The $\mathrm{pH}$ varied from slightly acid to neutral (6.14 to 7.02 ) and water electrical conductivity varied widely, from 38 to $184 \mu \mathrm{S} . \mathrm{cm}^{-1}$. Oxygen concentration was high (5.42 to $8.89 \mathrm{mg} . \mathrm{L}^{-1}$ ). Nutrient concentrations also varied widely among the water bodies where this species was found. Ferrato (1967) registered its occurrence in lotic environments at depths varying from 2 to $4 \mathrm{~m}$, in strong currents of moderate turbidity, on floating macrophytes. In the present study, this species also occurred in lotic environments, although the depth was not recorded.

D. odontoplax was frequently found associated with macrophytes, both scattered and in dense stands. It occurred in large reservoirs or in semi-lotic water bodies. It was found in a lake (Marreco Pond) and a semi-lotic environment (Tupã Reservoir) only in the Aguapeí unit. 
Table 1. Physical and chemical variables for the water bodies where Dunhenvedia odontoplax was recorded. Cond = water electrical conductivity; $\mathrm{DO}=$ Dissolved oxygen, $\mathrm{NO}_{3}=$ Nitrate $; \mathrm{P}$ inorg = Inorganic Phosphorus, $\mathrm{PTD}=$ Total Dissolved Phosphorus, $\mathrm{PT}=$ Total Phosphorus, NT = Total Nitrogen, Chlor $=$ Chlorophyll, $\mathrm{R}=$ Reservoir, $\mathrm{P}=$ Pond, A.F.S = Água Fria Stream.

\begin{tabular}{|c|c|c|c|c|c|c|c|c|c|c|c|}
\hline Localities & Latitude & Longitude & pH & $\begin{array}{c}\text { Cond } \\
\left(\mu \mathrm{S} . \mathrm{cm}^{-1}\right)\end{array}$ & $\begin{array}{c}\text { DO } \\
\left(\mathbf{m g . L ^ { - 1 }}\right)\end{array}$ & $\begin{array}{c}\mathbf{N O}^{3} \\
\left(\mu \mathbf{g} . \mathbf{L}^{-1}\right)\end{array}$ & $\begin{array}{l}\text { P inorg } \\
\left(\mu \text { g. } \mathbf{L}^{-1}\right)\end{array}$ & $\begin{array}{c}\text { PTD } \\
\left(\mu \text { g. } \mathbf{L}^{-1}\right)\end{array}$ & $\begin{array}{c}\text { PT } \\
\left(\mu \mathbf{g} . \mathbf{L}^{-1}\right)\end{array}$ & $\begin{array}{c}\text { NT } \\
\left(\mu \mathbf{g} . \mathbf{L}^{-1}\right)\end{array}$ & $\begin{array}{c}\text { Chlor } \\
\left(\mu \text { g.L }^{-1}\right)\end{array}$ \\
\hline $\begin{array}{l}\text { Volta Grande } \\
\text { Reservoir }\end{array}$ & - & - & 6.14 & 38 & 8.56 & 255.40 & 3.90 & - & 0.33 & 230.60 & 3.30 \\
\hline $\begin{array}{l}\text { Promissão } \\
\text { Reservoir - } \\
\text { Pongai }\end{array}$ & $\begin{array}{l}21 \mathrm{~S} \\
41^{\prime} 01{ }^{\prime},\end{array}$ & $\begin{array}{l}45 \mathrm{~W} \\
16 ' 29,\end{array}$ & 6.50 & 143 & 5.42 & 368.74 & 5.24 & 10.60 & 23.13 & 189.09 & 5.15 \\
\hline $\begin{array}{l}\text { Mouth of the } \\
\text { Peixe River }\end{array}$ & - & - & - & - & - & 521.01 & 8.17 & 15.62 & 11.72 & 149.60 & 5.33 \\
\hline $\begin{array}{l}\text { Três Irmãos - } \\
\text { A.F.S. }\end{array}$ & $\begin{array}{l}20^{\circ} \\
55^{\prime} 00^{\prime \prime}\end{array}$ & $\begin{array}{l}50^{\circ} \\
55^{\prime} 35^{\prime \prime}\end{array}$ & 7.02 & 184 & 7.89 & 354.41 & 4.07 & 12.53 & 6.11 & 99.10 & 3.84 \\
\hline $\begin{array}{l}\text { Dam of Jupiá } \\
\text { Reservoir }\end{array}$ & $\begin{array}{l}20^{\circ} \\
45^{\prime} 39^{\prime \prime}\end{array}$ & $\begin{array}{l}51^{\circ} \\
35^{\prime} 22^{\prime \prime}\end{array}$ & 6.95 & 72 & 7.95 & 199.93 & 2.91 & 3.86 & 15.24 & 95.10 & 1.70 \\
\hline Marreco Pond & - & - & 6.58 & 57 & 7.56 & 11.39 & 44.38 & 65.67 & 50.98 & 99.30 & 11.88 \\
\hline Tupã Reservoir & - & - & 6.66 & 114 & 8.89 & 339.48 & 7.97 & 9.34 & 5.65 & 144.80 & 1.99 \\
\hline
\end{tabular}

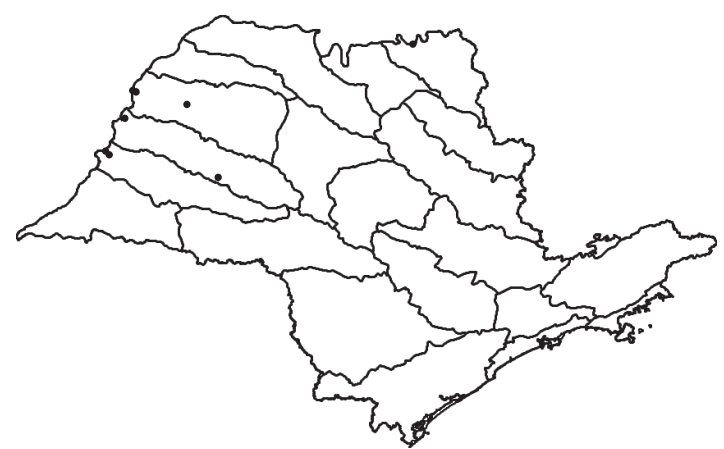

Figure 2. Map showing the distribution of Dunhenvedia odontoplax in the Water Resource Management Units of São Paulo State.

The occurrence in both lotic and lentic environments was already observed by Ferrato (1967).

Although still considered a rare species, the distribution of Dunhenvedia odontoplax in the State of São Paulo now extends from one to seven localities as a result of the wide sampling coverage performed in the BIOTA PROGRAM.

Acknowledgments - To FAPESP São Paulo State Research Aid Foundation, for financial support. This paper is a result of the Subproject "Zooplankton diversity and the state of degradation of São Paulo State freshwaters, part of the Biota/ FAPESP Program - The Institute of Virtual Biodiversity (www.biotasp.org.br).

\section{References}

BREHM, V., 1937. Brasilianische Cladoceren gesammelt von Dr. O. Schubart. Zweiter Bericht. Internationale revue der Gesamten Hydrobiologie und Hydrographie. vol. 35, p. 497-512.

-, 1938. Dritter Bericht über die von Dr. O. Schubart in Brasilien gesammelten Onychura. Zoologischer Anzeiger, Jena, vol. 122, p. 94-103.

FERRATO, AM., 1967. Zooplâncton. Anexo 3 (185-186). Orelana, J.A. Estudio limnologico de la laguna Paiva (Provincia de Santa Fe, Argentina), Physis, Buenos Aires, vol. 27, no. 74, p. $169-186$.

MONTÚ, M. and GLOEDEN, IM., 1986. Atlas dos Cladocera e Copepoda (Crustacea) do estuário da Lagoa dos Patos (Rio Grande, Brasil). Nerítica, Pontal do Sul, PR, vol. 1, no. 2, p. 1-134.

SARS, GO., 1901. Contribution to the knowledge of the freshwater Entomostraca od South America. Part I. Cladocera. Archv. for Mathematik og Naturvidenskab, Christiana, vol. 23, no. 3, p. 1-102.

SENDACZ, S., KUBO, E., and FUJARA. LP., 1983. Further Studies on the zooplankton community of a eutrophic reservoir in Southern Brazil. Verh. Internat. Verein. Limnol., vol. 22, p. $1625-1630$.

SMIRNOV, NN. 1996. Cladocera: the Chydorinae and Sayciinae (Chydoridae) of the World. Guides to the identification of the microinvertebrates of the continental waters of the world. SPB Academic Publishing. Netherlands., 197p.

SMIRNOV, NN. and SANTOS-SILVA, EN. 1995. Some littoral anomopods (Crustacea) from Central Amazônia. Hydrobiologia, vol. 315, p. 227-230. 